Original Article (short paper)

\title{
Sleep quality and psychobiological aspects of Brazilian Paralympic athletes in the London 2012 pre-Paralympics period
}

\author{
Dayane Ferreira Rodrigues \\ Universidade Federal de São Paulo, Brazil \\ Andressa Silva \\ Comitê Paralímpico Brasileiro, Brasilia, Brazil \\ João Paulo Pereira Rosa \\ Universidade Federal de Minas Gerais, Belo Horizonte, Brazil \\ Francieli Silva Ruiz \\ Universidade Federal de São Paulo, Brazil \\ Amaury Wagner Veríssimo \\ Ciro Winckler \\ Edilson Alves da Rocha \\ Andrew Parsons \\ Comitê Paralímpico Brasileiro, Brasília, Brazil \\ Sergio Tufik \\ Universidade Federal de São Paulo, SP, Brazil \\ Marco Tulio de Mello \\ Universidade Federal de Minas Gerais, Belo Horizonte, Brazil
}

\begin{abstract}
The objective of the study was to evaluate the psychobiological aspects of the Paralympic athletes athletics mode, before the London Paralympic Games 2012. We evaluated 40 athletes without 31 men and 9 women who were selected by the Brazilian Paralympic Committee to be part of the Brazilian delegation. For the evaluation of psychobiological aspects used questionnaires: Trait Anxiety Inventory-State, POMS, the Beck Depression questionnaire Pittsburgh Epworth Scale to assess, respectively, anxiety, mood, depression, sleep and sleepiness. For trait anxiety and state anxiety, athletes exhibited a mean level of anxiety in relation to the profile of mood states and higher intensity values than any other dimensions. The lower total sleep time was in athletes with bad sleep, sleep deficiency was lower in athletes with poor sleep and total sleep time was lower for those who had efficiency $<85 \%$. All psychobiological variables evaluated in pre-competition period were normal for the athletes of the Brazilian Paralympic athletics team that took part in the London 2012 Paralympic Games.
\end{abstract}

Keywords: disabled athletes, athletics, sports performance, psychobiological aspects

Resumo - "Qualidade de sono e aspectos psicobiológicos de atletas Paralímpicos brasileiros no período pré-Paralímpiadas de Londres 2012." O objetivo do estudo foi avaliar os aspectos psicobiológicos de atletas da modalidade de atletismo Paralímpico, antes dos Jogos Paralímpicos de Londres de 2012. Foram avaliados 40 atletas, sem 31 homens e 9 mulheres que foram convocados pelo Comitê Paralímpico Brasileiro para fazer parte da Delegação Brasileira. Para a avaliação dos aspectos psicobiológicos nós utilizamos os questionários: Inventário de Ansiedade Traço-Estado, POMS, Inventário de Depressão de Beck, questionário de Pittsburgh Escala de Epworth para avaliar, respectivamente, a ansiedade, o humor, a depressão, o sono e a sonolência. Para ansiedade-traço e ansiedade-estado os atletas apresentaram nível médio de ansiedade, em relação ao perfil dos estados de humor, a dimensão vigor apresentou valores mais altos do que as outras dimensões. O tempo total de sono foi menor em atletas com o sono ruim, a eficiência de sono foi menor em atletas com sono ruim e o tempo total de sono foi menor para quem teve eficiência $<85 \%$. Todas as variáveis psicobiológicas avaliadas no período pré-competitivo estavam dentro da normalidade para os atletas da equipe Paralímpica Brasileira de atletismo que participaram dos Jogos Paralímpicos de Londres 2012.

Palavras-chave: atletas com deficiência, atletismo, rendimento atlético, aspectos psicobiológicos 


\begin{abstract}
Resumen - “La calidad de sueño y los aspectos psicobiológicos de los atletas Paralímpicos brasileños en el período pre-Paralímpiadas de Londres 2012." El objetivo fue evaluar los aspectos psicobiológicos de los atletas de atletismo Paralímpico en el período que precedió los Juegos Paralímpicos de Londres de 2012. Se evaluaron 40 atletas. Los cuestionarios evaluaran la ansiedad, humor, depresión, sueño y la somnolencia. Para ansiedad-trazo y ansiedad-estado los atletas presentó nivel medio y no presentó propensión a la depresión. Los estados de humor la dimension vigor mostró un valor más alto. Para calidad de sueño los atletas presentó buen sueño, presentó somnolencia excesiva diurna y tuvo insatisfacción con el propio sueño. El tiempo total de sueño fue menor en atletas con un mal sueño, la eficiencia de sueño fue menor en atletas con un mal sueño y el tiempo total de sueño fue menor para quien tuvo eficiencia $<85 \%$. Las variables psicobiológicas evaluados en el período previo a los Juegos Paralímpicos de Londres de 2012 eran normales para los atletas de la selección brasileña.
\end{abstract}

Palabras claves: atletas con deficiencia, atletismo, rendimiento atlético, aspectos psicobiológicos

\section{Introduction}

Considering the increased competitiveness in recent years, analyzing and controlling the athletes' mental skills, for the purpose of improving their performance in high-level sports, is fundamental (Bertollo, Saltarelli, \& Robazza, 2009). The effects of the emotional state are evident in a highly competitive athletic environment, and psychological factors may affect athletic performance (Allen \& Jong, 2006).

Among the psychobiological factors that may determine athletes' athletic performance are sleep quality and its disorders; mood disorders, including anxiety and depression; and cognitive aspects, including memory and learning (De Mello, Boscolo, Esteves, \& Tufik, 2005). Mood state is regarded as a decisive factor in athletic performance. Alterations in mood state may have a negative effect on athletes during their training and/or competition (Devenport, Lane, \& Hanin, 2005).

The ability to handle the pressure and anxiety is an integral part of sport, although few studies have examined how Paralympic athletes address stressful situations in this context (Campbell \& Jones 2002a; Campbell \& Jones, 2002b, Silva et al., 2012). According to Campbell and Jones (2002a, 2002b), travel to the main international competitions, being away from home for an extended period (from 7 to 14 days), having to share a room with other athletes during competitions and competing after a sleepless night generate high levels of stress in athletes. Therefore, the analysis of sleep quality may provide significant information to aid in the athletes' preparation (Martins, De Mello, \& Tufik, 2001).

Sleep is identified by elite athletes, trainers and coaches as an important aspect of the post-exercise recovery process and is a critical factor for optimal physical and mental performance (Mackinnon, 1998). Because of these factors, it is extremely important to assess each athlete's total sleep time requirement, the presence of disturbances/sleep fragmentation and the sleep quality.

However, for the athlete to have good sleep quality, the intensity and volume of exercise must not exceed an optimal level because there is a better response in sleep quality when the overload is increased up to this optimal level. Conversely, there is a direct negative effect on sleep quality when the overload imposed by exercise exceeds this optimal level. Therefore, the analysis of sleep behavior may provide useful information regarding the athletes' level of preparation (Martins et al., 2001).
Thus, the objective of the present study was to assess psychobiological aspects, such as anxiety, mood state, depression and sleep quality of Paralympic athletes of the Brazilian athletics team prior to the London Paralympic Games.

\section{Methods}

The research was approved by Ethics Committee of the Federal University of Sao Paulo (CEP 0294/11).

\section{Subjects}

Forty athletes (31 men and 9 women) of the Brazilian Paralympic team who participated in track-and-field events were evaluated. Nine of these athletes were guides, 13 were visually impaired, five were physically disabled, eight were amputees, four had cerebral palsy and one had dwarfism. The athletes were summoned by the Brazilian Paralympic Committee to participate in the London 2012 Paralympic Games.

\section{Procedures}

All athletes freely signed the Informed Consent Form. The evaluations and the interview were conducted by a single evaluator who was previously trained to use the questionnaires in this study, with each interview lasting from 40 to 50 minutes. The athletes were evaluated in June 2012 (two months before the London Paralympic Games).

\section{Evaluations}

\section{State-Trait Anxiety Inventory}

Spielberger, Gorsuch, and Lushene (1970) developed the State-Trait Anxiety Inventory (STAI), which is characterized as an instrument with two parallel scales, each consisting of 20 items. One evaluates state anxiety (A-State), indicating how the subject is feeling at that 'moment', and the other evaluates trait anxiety (A-Trait), indicating how the subject 'generally feels.' The STAI was translated, adapted and validate for Brazil by 
Biaggio and Natalício (1979). The scoring is performed using the Likert scale, with scores ranging from 1 to 4 . The total score ranges from 20 to 80 points for each scale, and each score indicates a level of anxiety (Spielberger et al., 1970) that is low (20 to 30 points), middle from (31 to 49 points) or high (50 or greater). The estimated internal consistency of the Brazilian version as coefficient alpha was .89 for the total sample.

\section{Profile of Mood States}

The Profile of Mood States (POMS) consists of a list of 65 self-applicable adjectives, related to mood states, wherein participants must note how they feel about each adjective on a scale from 0 to 4 . Six mood factors or affective states are measured by this instrument: tension-anxiety, depression-dejection, anger-hostility, vigor-activity, fatigue-inertia and confusion -bewilderment. The score of each dimension is obtained by adding a few adjectives (McNair, Lorr, \& Droppleman, 1971).

The organization of results from the questionnaire in each dimension results in a graph, which enables researchers to evaluate the subject's mood profile. If an athlete scores low on "negative" mood scales (tension, depression, anger, fatigue, confusion) and high on the "positive" vigor scale, the plotted curve resembles an iceberg. Using this terminology, Morgan's hypothesis can be simplified as follows: Successful athletes possess more of an iceberg profile than less successful athletes. Athletes, especially successful ones, possessed a unique mood profile which labeled the iceberg profile (McNair, Lorr \& Droppleman, 1981). The sum of the scores (with vigor weighted negatively) on the six primary mood factors results a score of total mood disturbance. The five scales scores of tension, depression, anxiety, fatigue and confusion are added together and vigor is subtracted from these scores. Higher scores for the total mood disturbance score indicate a greater degree of mood disturbance (Mcnair, Lorr, \& Droppleman, 1992). Translation and validation in Portuguese POMS were realized by Peluso (2003) in a study of mood changes associated with physical activity.

\section{Beck Depression Inventory}

The Beck Depression Inventory (Beck Depression inventory- BDI) was created by Beck and colleagues (1961) and the validation of Portuguese version was performed by Gorenstein and Andrade (1996). The items in the Beck Depression Inventory (BDI), are designed to evaluate the following symptoms and attitudes: sadness, pessimism, sense of failure, lack of satisfaction, guilt feelings, sense of punishment, self-dislike, self-accusation, suicidal wishes, crying, irritability, social withdrawal, indecisiveness, distorted body image, work inhibition, sleep disturbance, fatigability, loss of appetite, weight loss, somatic preoccupation and loss of libido. A normal depression level is indicated by a score from 0 to 9 points, minimal is from 10 to 15 points, minimal to moderate is from 16 to 19 points, moderate to severe is from 20 to 29 points and severe is from 30 to 63 points (Beck, Ward, Mendelson, Mock, \& Erbaugh,
1961). The internal consistency (coefficient alpha) of the Brazilian version of BDI was .81 for the student sample (.83 for females and .76 for males) and .88 for the depressed sample (Gorenstein \& Andrade, 1996).

\section{Pittsburgh Sleep Quality Index}

The Pittsburgh Sleep Quality (PSQI) was developed by Buysse, Reynolds, Monk, Berman, and Kupfer (1989), and the validation of Brazilian Portuguese version was developed by Bertozali et al. (2010). This questionnaire consists of 11 questions grouped into seven domains relating to complaints regarding sleep, subjective sleep quality, sleep latency, sleep duration, habitual sleep efficiency, sleep disturbances, use of sleeping medication and daytime dysfunction. The scores of the seven domains are added to an overall score, which ranges from 0 to 21 . Scores from 0 to 4 points indicate good quality of sleep and from 5 to 10 points poor quality. Scores above 10 points indicate the person most likely has a sleep disorder (Buysse et al., 1989). The seven-component scores of the Brazilian Portuguese version had an overall reliability coefficient of .82, indicating a high degree of internal consistency.

\section{Epworth Sleepiness Scale}

The Epworth Sleepiness Scale (ESS) was published by Johns (1991) and the validation of Portuguese language version of the scale for use in Brazil was performed by Bertozali and colleagues (2009). This scale provides an overall measure of the daytime sleepiness level in adults by evaluating excessive sleepiness in various active and passive situations. The situations are sitting and reading; watching television; sitting in a public place; riding in a train, car or bus (for an hour without a break); lying down to rest in the afternoon; sitting and talking to someone; sitting quietly after lunch without alcohol intake; and in a car, while stopped for a few minutes in traffic. The respondent must rate the chance of dozing off or falling asleep in each situation, using a score from 0 (no chance) to 3 (high chance). The reference values are 0-6: normal; 7-9: borderline; 10-14: minimal; 15-20: moderate; and above 20: severe. The eight items of the Brazilian scale had an overall reliability coefficient of .83 (Bertolazi et al., 2009).

\section{Sleep Questionnaire}

The UNIFESP sleep questionnaire created by Pires, Benedito-Silva, Mello, Pompeia Sdel, and Tufik (2007) has questions regarding the respondent's satisfaction with their own sleep and a series of items relative to parasomnias (somnambulism, bruxism, sleep apnea, epilepsy, asthma, nocturnal panic, tachycardia, gastric reflux, headaches, post-nightmare anxiety, snoring, leg cramps and leg movement) and how often they occur (never, rarely, two to three times/month, one to two times/ week, three to six times/week or always). 
Table 1. Frequency of athletes with propensity to anxiety and depression.

\begin{tabular}{lccc}
\hline Anxiety & Low level & Middle level & High level \\
Trait & 14 athletes $(35 \%)$ & 25 athletes $(62.5 \%)$ & 1 athlete $(2.5 \%)$ \\
State & 13 athletes $(32.5 \%)$ & 25 athletes $(62.5 \%)$ & 2 athletes $(5 \%)$ \\
Depression & & & Moderate to severe \\
Normal & Minimal & Minimal to moderate & 1 athletes $(2.5 \%)$ \\
32 athletes $(80 \%)$ & 2 athletes $(5 \%)$ &
\end{tabular}

\section{Statistical analysis}

The results are expressed as the mean \pm standard deviation, and the level of significance was set at $p \leq .05$. Variables with non-parametric distributions were normalized using the $Z$-score. The associations between qualitative variables were quantified using the chi-squared test. Analyses of the different quantitative parameters were performed using the general linear model (GLM), considering group the main factor, and Student's t-test for comparisons between groups, using PASW 18 software.

\section{Results}

The athletes had a mean age of $30.08 \pm 7.07$ years; mean body weight of $69.67 \pm 15.03 \mathrm{~kg}$ and mean height of $170 \pm 0.11$ $\mathrm{cm}$. Table 1 shows the frequency data of anxiety and depression in athletes one month before the London Paralympics. Just over half the athletes $(62.5 \%)$ had a middle-level propensity for trait anxiety. The same frequency was found for state anxiety $(62.5 \%)$, also at a middle level. In addition, $80 \%$ of the athletes showed no propensity for depression.
The mean and the standard deviation of each dimension of the profile of mood states are shown in Figure 1. The mean of the scores showed a profile known as iceberg evidenced by the increased of vigor dimension in relation to the other dimensions.

The frequencies of sleep quality, latency and efficiency and excessive daytime sleepiness are show in Table 2.

Regarding the PSQI sleep quality, $62.5 \%$ of the athletes showed good sleep, $67.5 \%$ showed sleep latency shorter than 20 minutes and $92.5 \%$ had sleep efficiency greater than $85 \%$. The mean total sleep time in the group was $7.3 \pm 1.2$ hours/ night. The frequency of excessive daytime sleepiness assessed by the ESS was $52.5 \%$.

We observed that $46.3 \%$ athletes need or would like to change some aspect of their own sleep. Among the desired changes reported by athletes were delaying the period of sleep (9.3\%), advancing the period of sleep $(3.7 \%)$, increasing sleep time $(24.1 \%)$ and other types of changes $(4 \%)$.

Regarding the frequency of sleep complaints in athletes, the most reported were headache (14.8\% rarely, 5.6\% $1-2$ times/ week, 1.9\% 2-3 times/month, 3.7\% always), post-nightmare anxiety (13\% rarely, 1.9\% 1-2 times/week, 3.7\% 2-3 times/ month), snoring (14.8\% rarely, 5.6\% 1-2 times/week, $3.7 \%$

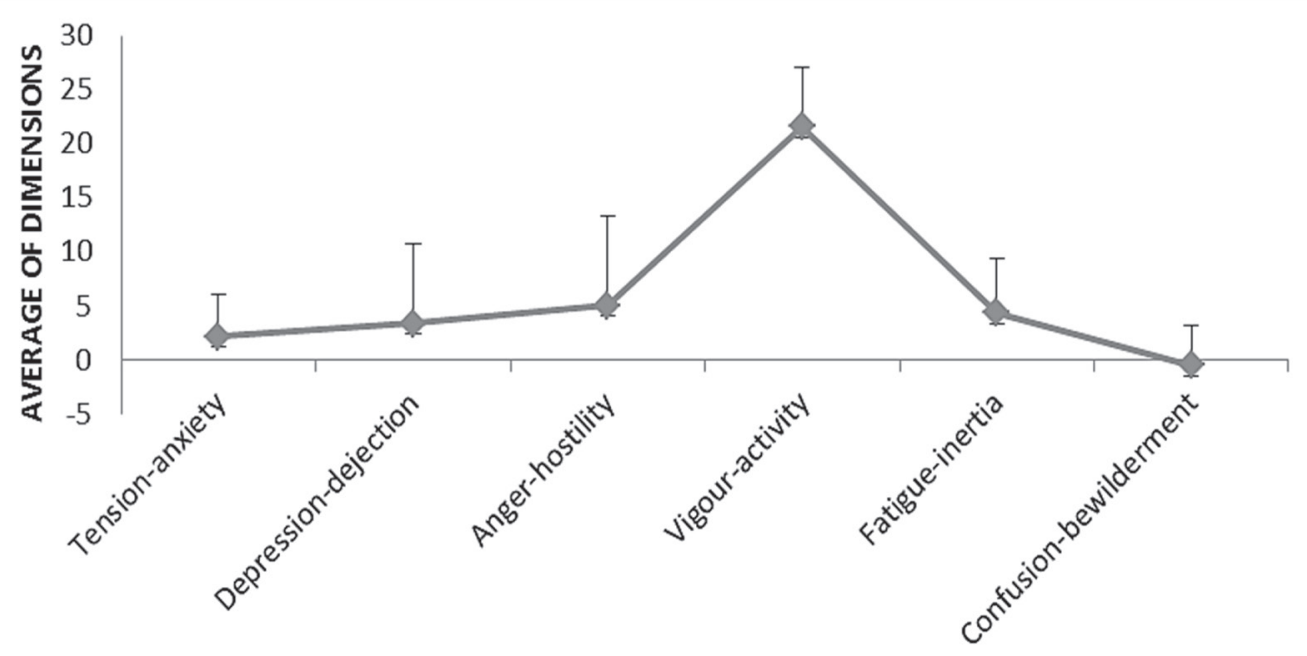

Figure 1. Average and standard deviation of the dimensions assessed in the POMS questionnaire. 
Table 2. Frequency of athletes with good or poor sleep quality, sleep latency and efficiency, excessive daytime sleepiness.

\begin{tabular}{lcc}
\hline Sleep quality & Good Quality & 25 athletes $(62.5 \%)$ \\
& Poor Quality & 15 athletes $(37.5 \%)$ \\
Sleep latency & $<20(\mathrm{~min})$ & 27 athletes $(67.5 \%)$ \\
& $\geq 20(\mathrm{~min})$ & 13 athletes $(32.5 \%)$ \\
Sleep efficiency & $<85 \%$ & 3 athletes $(7.5 \%)$ \\
& $>85 \%$ & 37 athletes $(92.5 \%)$ \\
Sleepiness & Normal & 19 athletes $(47.5 \%)$ \\
\hline
\end{tabular}

2-3 times/month, 1.9\% 3-6 times/week, 5.6\% always), muscle cramps (20.4\% rarely, 3.7\% 1-2 times/week) and leg movement (14.8\% rarely, 5.6\% 1-2 times/week, 5.6\% 2-3 times/month, $9.3 \%$ always).

Table 3 shows an association between anxiety and good or poor sleep quality and between depression and good or poor sleep quality. Regarding trait anxiety, it is noteworthy that $37.5 \%$ of athletes who showed middle-level anxiety also showed good sleep quality. However, this association was not statistically significant $(p=.33)$. Regarding state anxiety, $32.5 \%$ of athletes reported middle-level anxiety and good sleep quality, although this association was not statistically significant $(p=.13)$. Regarding depression, $57.5 \%$ athletes who showed no propensity for depression had good sleep quality. That association was not statistically significant, although it trended towards significance $(p=.07)$.

Figure 2 shows an evaluation of the sleep latency among subjects with good or poor sleep quality. A statistically significant difference was found between groups $\left(F_{1,38}=12.59, p=\right.$
.001 ; effect size $=.24$; effect power $=.93)$. Sleep latency was noticeably higher in subjects with poor sleep quality $(p<.001)$. Figure 2 also shows an evaluation of the existing difference in total sleep time among subjects with good or poor sleep quality. A statistically significant difference was found between groups $\left(F_{1,38}=9.02 ; p=.05\right.$; effect size $=.19$; effect power $=$ $.83)$. The total sleep time was shorter in athletes who showed poor sleep quality $(p=.005)$. Furthermore, Figure 2 shows the sleep efficiency in subjects with good and poor sleep quality. A statistically significant difference was found between groups $\left(F_{1,38}=16.99\right.$; effect size $=.30$; effect power $\left.=.98\right)$. The sleep efficiency was noticeably lower in athletes who showed poor sleep quality $(p<.001)$.

Figure 3 shows an evaluation of total sleep time in subjects with sleep efficiency higher or lower than $85 \%$. A statistically significant difference was found between groups $\left(\mathrm{F}_{1,39}=16.58\right.$, $p<0.001$; effect size $=.29$; effect power $=.97$ ). The total sleep time was shorter for the athletes who had less than $85 \%$ efficiency $(p=.01)$.

Table 3. Associations of trait and state-anxiety and depression with good or poor sleep quality.

\begin{tabular}{lllll}
\hline Evaluations & & $\begin{array}{l}\text { Good quality } \\
\mathbf{n}(\mathbf{\%})\end{array}$ & $\begin{array}{l}\text { Poor quality } \\
\mathbf{n}(\mathbf{\%})\end{array}$ & $\begin{array}{l}\text { Total } \\
\mathbf{n}(\mathbf{\%})\end{array}$ \\
\hline \multirow{3}{*}{ Trait-Anxiety } & Low & $10(25 \%)$ & $4(10 \%)$ & $14(35 \%)$ \\
& Middle & $15(37.5 \%)$ & $10(25 \%)$ & $25(62.5 \%)$ \\
& High & $0(0 \%)$ & $1(2.5 \%)$ & $1(2.5 \%)$ \\
& Total & $25(62.5 \%)$ & $15(37.5 \%)$ & $40(100 \%)$ \\
State-Anxiety & Low & $11(27.5 \%)$ & $2(5 \%)$ & $13(32.5 \%)$ \\
& Middle & $13(32.5 \%)$ & $12(30 \%)$ & $25(62.5 \%)$ \\
& High & $1(2.5 \%)$ & $1(2.5 \%)$ & $40(100 \%)$ \\
Detal & $25(62.5 \%)$ & $15(37.5 \%)$ & $32(80 \%)$ \\
& Normal & $23(57.5 \%)$ & $9(22.5 \%)$ & $5(12.5 \%)$ \\
& Minimal & $1(2.5 \%)$ & $4(10 \%)$ & $2(5 \%)$ \\
& Minimal to Moderate & $1(2.5 \%)$ & $1(2.5 \%)$ & $1(2.5 \%)$ \\
& Moderate to Severe & $0(0 \%)$ & $1(2.5 \%)$ & $40(100 \%)$ \\
\hline
\end{tabular}



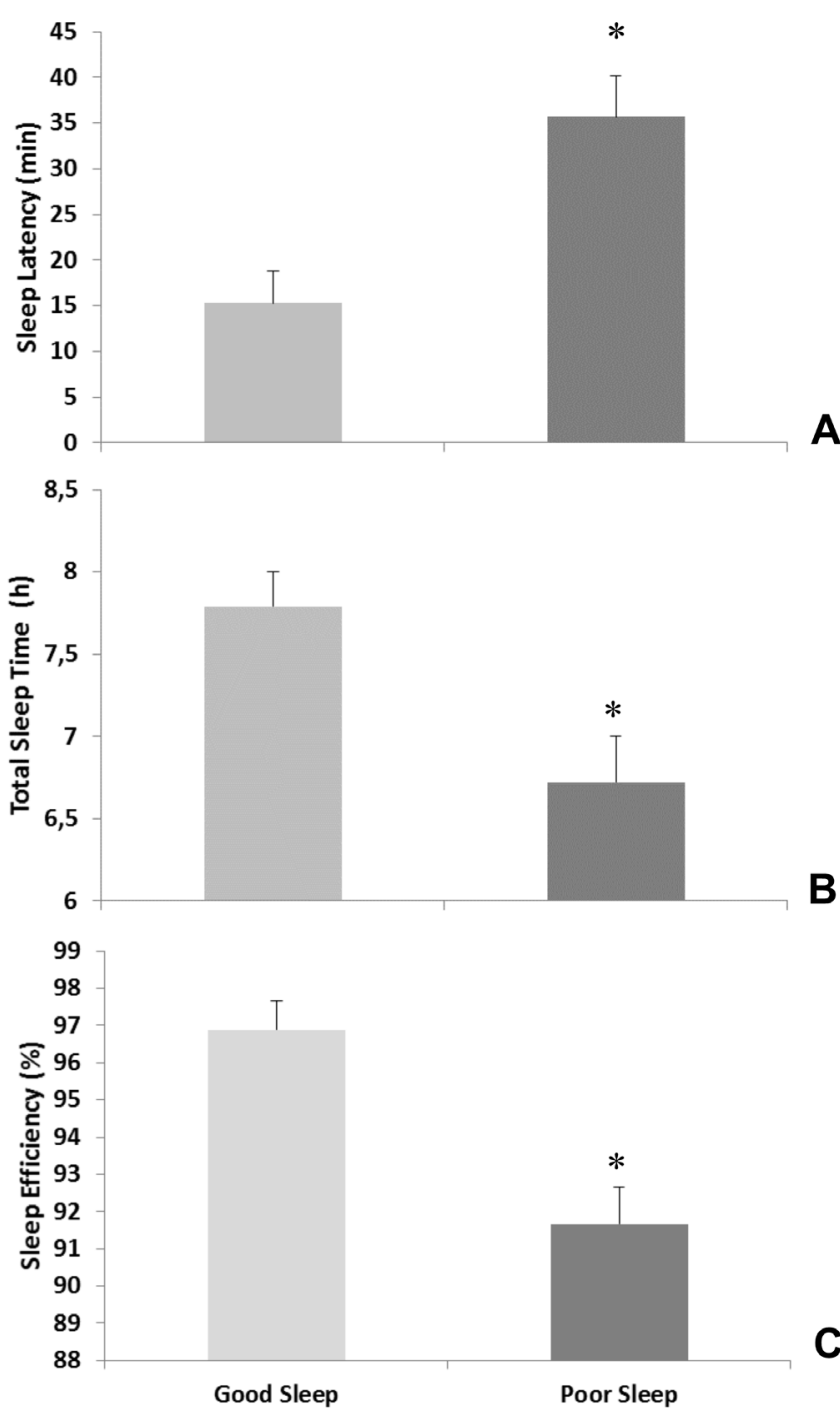

Figure 2. Evaluation of differences in sleep latency (A), total sleep time (B) and sleep efficiency (C) among subjects with good or poor sleep quality, using the Pittsburgh Questionnaire. * $p \leq .05$ is defined as statistically significant.

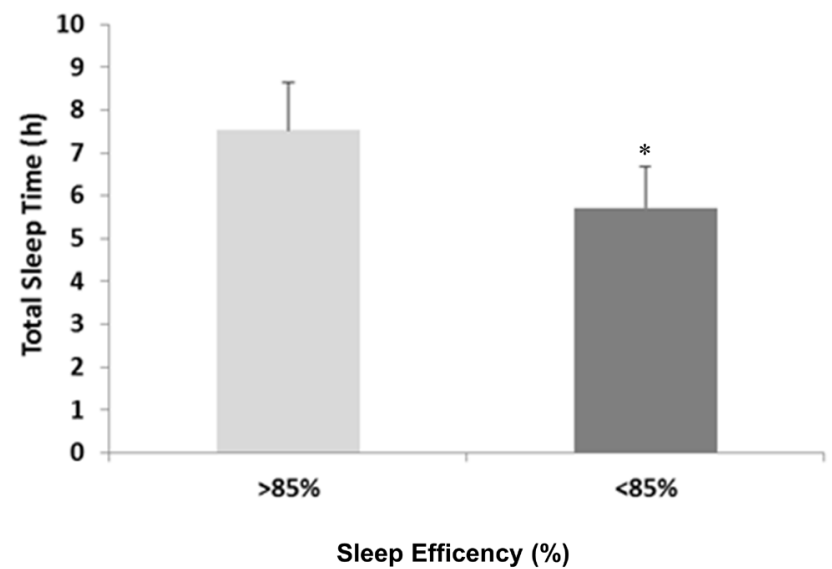

Figure 3. Association of total sleep time and sleep efficiency higher or lower than $85 \%$, using the Pittsburgh Questionnaire. $\alpha \leq 5 \%$ is defined as statistically significant.

\section{Discussion}

The present study shows that most athletes had middle-level anxiety, no propensity to depression and a positive mood state. Regarding sleep quality, athletes mostly showed good sleep quality in all aspects evaluated. Therefore, the psychobiological analyses should be considered an auxiliary instrument to detect whether athletes are mentally prepared to address their competitive environment, in addition to physical preparation.

Our findings indicate that athletes had middle-level state-trait anxiety before the competition. This result corroborates those reported by Silva et al. (2012), who also found middle-level state-trait anxiety when evaluating athletes before the Beijing Paralympic Games. According to Weinberg and Gould (1995), there is a direct relationship between trait anxiety and state anxiety. Our results show similarities with those of Halvari and Gjesme (1995), who found that middle-level anxiety is associated with better performance during a competition than low and high levels of anxiety.

The POMS results showed a lower total mood disturbance and a profile known as iceberg, where the vigor dimension appeared more evident than the other dimensions, suggesting no significant presence of mood disorders. Athletes who show positive mood states (high vigor associated with low levels of fatigue, anger, tension, depression and confusion) may have the best athletic performance (Micklewright, Griffin, Gladwell, \& Beneke, 2005; Bertollo et al., 2009).

Morgan and Pollock (1977) studied the differences of mood states among individuals practicing and not sport practitioners. Practitioners individuals in any sport have, compared to non -practicing population, consistently higher results in the range of vigor, and lower results in negative 5 scales of the POMS, tension, depression, hostility, fatigue and confusion.

Most athletes (80\%) showed no propensity for depression. The main causes of depression in athletes are failure, which generates low self-esteem, unhappiness, lack of pleasure and dissatisfaction, and physical injuries, which increase anxiety and generate depression, thus leading to low self-esteem (Eldridge, 1983; Wiese \& Weiss, 1987). Physical injuries in athletes lead to a serious psychological disorder, increasing the risk for suicide (Smith \& Milliner, 1994). The present athletes were evaluated before the competition, and none of them were injured, which further decreased the risk for depression in that group.

In the present study, $62.5 \%$ of the athletes showed good sleep quality. Sleep latency was highest in subjects with poor sleep quality. These findings corroborate the findings of Silva et al. (2012), who also found that sleep latency was higher in the group with poor sleep quality among Paralympic athletes in the period before the Beijing Paralympic Games. Walker and Stickgold (2005) stressed the importance of proper sleep, in terms of both quantity and quality, to ensure the athletes perform well when cognitive and psychomotor skills are required.

The mean total sleep time in the present study was $7.3 \pm 1.2$ hours/night. The total sleep time was shorter in athletes who showed poor sleep and who had sleep efficiency lower than $85 \%$. According to Driver and Taylor (2000), trained subjects have longer total sleep time than sedentary subjects without training, 
which reinforces the need for increased sleep levels to restore homeostasis disturbed by exercise. Therefore, good-quality sleep is essential for athletes' physical and mental recovery.

The $92.5 \%$ sleep efficiency found in our study is considered optimal (> 85\%) for recovering the biological functions performed during the preceding period of wakefulness (Fernandes, 2006). Furthermore, sleep efficiency was noticeably lower in athletes who showed poor sleep quality. The improvement in sleep efficiency compared to data from the 2008 Beijing Paralympics (Silva et al., 2012), wherein 27 track-and-field Paralympic athletes were evaluated and showed a sleep efficiency of $78.5 \%$, is noteworthy.

In the present study, $52.5 \%$ of the athletes showed excessive daytime sleepiness, which may be explained by the fact that $46.3 \%$ of the athletes were dissatisfied with their own sleep and by the frequency of sleep complaints in those athletes, the most reported ones being headache, post-nightmare anxiety, snoring, leg cramps and leg movement.

Our subjects' dissatisfaction with their own sleep corroborates data found by De Mello, Esteves, Comparoni, BeneditoSilva, and Tufik (2002), who evaluated Paralympic athletes participating in the 2000 Sydney Paralympic Games and found that $34.4 \%$ of the athletes showed dissatisfaction with their own sleep, differing only in some of the most reported sleep complaints, namely, apnea (14\%), gastric reflux (15.6\%), headache (14.1\%), post-nightmare anxiety (39.1\%), muscle cramps (20.3\%), sleep-talking (26.6\%), nocturnal panic $(9.4 \%)$, leg movement $(9.4 \%)$ and bruxism $(9.4 \%)$.

Athletes with middle-level anxiety showed good sleep quality. According to Almondes and Araújo (2003), trait anxiety is a characteristic of an individual's personality, that is, an endogenous factor that may affect the temporal expression of the pattern of sleep-wake cycle. Conversely, an irregular pattern of sleep-wake cycle may be affected by exogenous factors, which apparently contributes to an increased state of anxiety. The factors that may affect the level of anxiety in athletes, according to Guzmán, Amar, and Ferreras (1995), are the level of demand involved in the situation, including the demand from the self, coaching staff, family, and fans; and, especially, the fear of failure experienced by the athlete.

Regarding depression, most athletes showed no propensity to depression and showed good sleep quality. According to Harvey (2001), depressed patients have complaints related to changes in sleep patterns, and the main disorder is insomnia. In some cases, insomnia is caused by the depression medication, which may have stimulating properties. The athletes in this study presumably had no complaints of insomnia and thus slept better and had no propensity for depression related to sleep quality because $67.5 \%$ of the athletes had sleep latency shorter than 20 minutes.

The findings of the present study show that the Brazilian Paralympic athletics team was mentally prepared to face this highly competitive environment, resulting in a good performance with an impressive number of medals. Brazil is one of the countries that have shown significant progress in recent editions of the Paralympic Games, attaining $24^{\text {th }}$ place in the Sydney Games in $2000,14^{\text {th }}$ place in Athens in 2004, $9^{\text {th }}$ place in Beijing in 2008 and $7^{\text {th }}$ place in London in 2012. The 2012 Brazilian athletics team was responsible for the highest number of medals ( 7 gold, 8 silver and 3 bronze) of the Brazilian Paralympic Delegation. Furthermore, this Paralympic team was monitored for four years by a multidisciplinary team (physicians, physiotherapists, nutritionists, physical education professionals and physiologists), which contributed to our findings and, consequently, the success of the athletes themselves. A recent literature review discussed evidence-based psychological preparation strategies being employed by the athletes who will compete in the upcoming 2014 Winter Paralympic Games. It concluded that sport psychologists may help athletes develop mental skills to manage stress before a competition, increasing the chances of having a better athletic performance (Martin, 2012).

Some limitations of this study need to be addressed as the heterogeneity of the sample recruited (man and women athletes, with different disabilities, competing in different tests of athletics, with different functional classification). In addition, our results come from questionnaires and despite all data collection instruments are validated, there are inherent limitations to the method, as difficulty in understanding the interviewed volunteers, in which during the application of the tests were read all issues, and there may be the influence of an answer, because the items may have different meanings for each subject.

\section{Conclusion}

Thus, we can conclude that all psychobiological variables (anxiety, mood states, depression and sleep quality) of athletes from the Brazilian Paralympics team evaluated in the pre-competition period were within normal values. These data suggest that monitoring Paralympic athletes' psychobiological profiles before an athletic competition may be a determining factor for satisfactory performance.

\section{References}

Allen, J.B., \& Jong, M.R. (2006). Sailing and sports medicine: a literature review. Britsh Journal of Sports Medicine, 40, 587-593. doi: $10.1136 /$ bjsm.2002.001669

Almondes, K.M \& Araújo, J.F. (2003). Padrão do ciclo sono-vigília e sua relação com a ansiedade em estudantes universitários (Default sleep-wake cycle and its relationship with anxiety in college students). Estudos de Psicologia, 8, 37-43. [Retrieved from http:// dx.doi.org/10.1590/S1413-294X2003000100005]

Beck, A.T., Ward, C.H., Mendelson, M., Mock, J., \& Erbaugh, J. (1961) An inventory for measuring depression. Archives of General Psychiatry, 14,561-71. doi:10.1001/archpsyc.1961.01710120031004

Bertolazi, A.N., Fagondes, S.C., Hoff, L.S., Pedro, V.D., Menna Barreto, S.S., \& Johns, M.W. (2009). Validação da escala de sonolência de Epworth em português para uso no Brasil (Validation of Epworth sleepiness scale in Portuguese for use in Brazil). Jornal Brasileiro de Pneumologia, 35, 877-883.

Bertollo, M., Saltarelli, B., \& Robazza, C. (2009). Mental preparation strategies of elite modern pentathletes. Psychology of Sport and Exercise, 10, 244-254. doi.org/10.1016/j.psychsport.2008.09.003

Biaggio, A.M.B., \& Natalicio, L. (1979). Manual para o Inventário de 
Ansiedade Traço-Estado (IDATE) (Manual to stait-trait inventory). Rio de Janeiro, Brasil: Centro Editor de Psicologia Aplicada-CEPA.

Buysse, D.J., Reynolds, C.F., Monk, T.H., Berman, S.R., \& Kupfer, D.J. (1989). The Pittsburgh Sleep Quality Index: a new instrument for psychiatric practice and research. Psychiatry Research, 28,193213. doi.org/10.1016/0165-1781(89)90047-4

Campbell, E., \& Jones, G. (2002a). Sources of stress experienced by elite male wheelchair basketball players. Adapted Physical Activity Quartely, 19, 82-99. [Retrieved from

http://journals.humankinetics.com/AcuCustom/Sitename/Documents/ DocumentItem/5510.pdf]

Campbell, E., \& Jones, G. (2002 b).Cognitive appraisal of sources of stress experienced by elite male wheelchair players. Adapted Physical Activity Quartely, 19,100-108. (Retrieved from http:// journals.humankinetics.com/AcuCustom/Sitename/Documents/ DocumentItem/5511.pdf)

De Mello, M.T., Boscolo, R.A., Esteves, A.M., \& Tufik, S. (2005). O exercício físico e os aspectos psicobiológicos (Physical exercise and psychobiological aspects). Revista Brasileira de Medicina do Esporte, 11, 203-207. doi.org/10.1590/S1517-86922005000300010

De Mello, M.T., Esteves, A.M.,Comparoni, A., Benedito-Silva, A.A., \& Tufik, S. (2002). Avaliação do padrão e das queixas relativas ao sono, cronotipo e adaptação ao fuso horário dos atletas brasileiros participantes da Paraolimpíada em Sidney - 2000 (Evaluation of the pattern and sleep-related complaints, cronotipo and adaptation to time zone of the Brazilian athletes participating in the Paralympics in Sydney-2000). Revista Brasileira de Medicina do Esporte. 8, 122-128. (doi.org/10.1590/S1517-86922002000300010.

Devenport, T.J., Lane, A.M., \& Hanin, Y.L. (2005). Emotional states of athletes prior to performance-induced injury. Journal of Sports Science and Medicine, 4,382-394. (Retrieved from http://www. jssm.org/vol4/n4/4/v4n4-4pdf.pdf)

Driver, H.S., \& Taylor, S.R. (2000).Exercise and sleep. Sleep Medicine Reviews, 4, 387-402. doi.org/10.1053/smrv.2000.0110

Eldridge, W.D. (1983). The importance of psychotherapy for athletic -related orthopedic injuries among adults. Comprehensive Psychiatry, 24,271-277. http://dx.doi.org/10.1016/0010-440X(83)90079-2

Fernandes, R.M.F. (2006). O sono normal (The normal sleep). (Unpublished manuscript). In: Simpósio de Distúrbios Respiratórios do Sono. Medicina, Ribeirão Preto. 2 (39),157-168.

Gorenstein, C., \& Andrade, L. (1996). Validation of a Portuguese version of the Beck Depression Inventory and the State-Trait Anxiety Inventory in Brazilian subjects. Brazilian Journal of Medical and Biological Research, 29, 453-457.

Guzmán, J.I.N., Amar, J.R.,\& Ferreras, C.G (1995). Ansiedad precompetitiva y conductas de autocontrol en jugadores de futbol (Pre-competitive anxiety and behavior of self-control in soccer players). Revista de Psicologia del Deporte. 7,7-17. (Retrieved from http://ddd.uab.cat/pub/revpsidep/19885636v4n2p7.pdf)

Halvari, H., \& Gjesme, T. (1995). Trait and State Anxiety Before and After Competitive Performance. Perceptual Motor Skills, 81, 1059-1074. doi: 10.2466/pms.1995.81.3f.1059

Harvey, A.G. (2001) Insomnia: Symptom or Diagnosis? Clinical Psychology Review, 21, 1037-1059. doi: 10.1016/S02727358(00)00083-0

Johns, M.W. (1991). A new model for measuring daytime sleepiness: the Epworth Sleepiness Scale. Sleep, 14, 540-545.

Mackinnon, L.T. (1998). Effects of overreaching and overtraining on imune function. In: R.B Kreider, A.C. Fry, and M.L O'Toole (Eds). Overtraining in sport. (pp. 219-242). Windsor (Ontario): Human Kinetics Publishers.

Martin, J. (2012). Mental Preparation for the 2014 Winter Paralympic Games. Clinical Journal of Sport Medicine, 22, 70-73. doi:10.1097/
JSM.0b013e31824204cc

Martins, P.J.F., De Mello, M.T., \& Tufik, S. (2001). Exercício e sono (Exercise and sleep). Revista Brasileira de Medicina do Esporte, 7, 28-36. doi.org/10.1590/S1517-86922001000100006

McNair, D.M., Lorr, M., \& Droppleman, L.F. (1971). Manual for the Profile of Mood States. San Diego, CA: Educational and Industrial Testing Services.

McNair, P.M., Lorr, M., \& Droppleman, L.F. (1981). POMS manual (2nd ed.). San Diego: Educational and Industrial Testing Service.

McNair, D.M., Lorr, M., \& Droppleman, L.F. (1992). Revised manual for the Profile of Mood States. San Diego, CA: Educational and Industrial Testing Services.

Micklewright, D., Griffin, M., Gladwell, V., \& Beneke, R. (2005). Applied Research Mood state response to massage and subsequent exercise performance. The Sport Psychologist, 19, 234-250. (Retrieved from: http://www.scielo.br/scielo.php?script=sci nlinks\&re$\mathrm{f}=000119$ \& pid $=$ S1980-6574201000040000300015\&lng=en)

Morgan, W.P., Pollock, M.L. (1977). Psychological characterization of the elite distance runner. Annals of the New York Academy of Sciences, 301, 382-403.

Pires, M.L., Benedito-Silva, A,A., Mello, M.T., Pompeia Sdel, G., \& Tufik, S. (2007). Sleep habits and complaints of adults in the city of São Paulo, Brazil, in 1987 and 1995. Brazilian Journal of Medical Biological Research, 40, 1505-1015. doi.org/10.1590/ S0100-879X2006005000170

Peluso, MAM. (2003). Alterações de humor associadas a atividade física intensa (Mood changes associated with intense physical activity). Doctoral dissertation, Universidade de São Paulo, SP, Brazil.

Silva, A., Queiroz, S.S., Winckler, C., Vital, R., Sousa, R.A., Fagundes, V., ... De Mello, M.T. (2012). Sleep quality evaluation, chronotype, sleepiness and anxiety of Paralympic Brazilian athletes: Beijing 2008 Paralympic Games. British Journal of Sports Medicine, 46,150-154. doi: 10.1136/bjsm.2010.077016

Smith, A.M., \& Milliner, E.K. (1994). Injured athletes and the risk of suicide. Journal of Athletic Training, 29, 337-341. (Retrieved from: http://www.ncbi.nlm.nih.gov/pmc/articles/PMC1317809/)

Spielberger, C.D., Gorsuch, R.L., \& Lushene, R.E. (1970). The statetrait anxiety inventory (Self Evaluation Questionnaire). Palo Alto, CA: Consulting Psychologists Press.

Walker, M.P., \& Stickgold, R. (2005). It's practice, with sleep, that makes perfect: implications, of sleep-dependent learning and plasticity for skill performance. In: T. Postolache (Ed.). Sports chronobiology. Clinics Sports Medicine (pp 301-318). Philadelphia: W.B Saunders Company.

Weinberg, R., \& Gould, G. (1995). Foundations of sport and exercise psychology. Champaign: Human Kinetics.

Wiese, D., \& Weiss, M. (1987). Psychological Rehabilitation and Physical Injury: Implications for the Sports Medicine Team. The Sport Psychologist, 1, 318-330.

\section{Authors' note}

Dayane Ferreira Rodrigues is affiliated with Universidade Federal de São Paulo, Brazil.

Andressa Silva is affiliated with the Universidade Federal de Minas Gerais, Belo Horizonte, Brazil and the Comitê Paralímpico Brasileiro, Brasília, Brazil

João Paulo Pereira Rosa and Marco Túlio de Mello are affiliated with the Universidade Federal de São Paulo, SP, Brazil and Universidade Federal de Minas Gerais, Belo Horizonte, Brazil. 
Francieli Silva Ruiz and Sergio Tufik are affiliated with the Psychobiology and Exercise Research Center, Universidade Federal de São Paulo, Brazil

Amaury Wagner Veríssimo, Ciro Winckler, Edilson Alves da Rocha, and Andrew Parsons are affiliated with the Comitê Paralímpico Brasileiro.

\section{Acknowledgments}

The authors express their gratitude to Associação Fundo de Incentivo à Pesquisa - AFIP, Centro de Estudos em Psicobiologia e Exercício - CEPE, Conselho Nacional de Desenvolvimento Científico e Tecnológico - CNPq, Comitê Paralímpico Brasileiro - CPB, Academia Paralímpica Brasileira-APB and all the research assistants, especially Professor Dr Fabio Lira and the physicians, coaches and players who participated in this project. This study was funded by the Associação Fundo de Incentivo à Pesquisa (AFIP).

\section{Corresponding author}

Marco Tulio de Mello

Av. Presidente Carlos Luz, 4664, Pampulha, Belo Horizonte 31.310.250, MG, Brazil

Phone: 553134092348

E-mail: tmello@demello.net.br

Manuscript received on November 11, 2014

Manuscript accepted on April 14, 2015

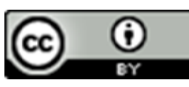

Motriz. The Journal of Physical Education. UNESP. Rio Claro, SP, Brazil - eISSN: 1980-6574 - under a license Creative Commons - Version 3.0 